UDC 614.7:34

DOI: 10.21668/health.risk/2018.3.04.eng

\title{
THE RF FEDERAL LAW “ON CHEMICAL SAFETY” AS A TOOL FOR MINIMIZING POPULATION HEALTH RISKS CAUSED BY DEALING WITH HAZARDOUS CHEMICAL WASTES
}

\author{
M.V. Pushkareva ${ }^{1,2}$, M.P. Shevyreva ${ }^{1,3}$, N.N. Goncharuk ${ }^{1}$, I.V. May ${ }^{4}$, A.M. Andrishunas ${ }^{4}$ \\ ${ }^{1}$ Centre for Strategic Planning and Management of Biomedical Health Risks, Russian Ministry of Health, Bldg. 1, \\ 10 Pogodinskaya Str., Moscow, 119121, Russian Federation \\ ${ }^{2}$ Perm National Research Polytechnic University, 29 Komsomolskiy avenue, Perm, 614990, Russian Federation \\ ${ }^{3}$ I.M. Sechenov First Moscow State Medical University, Build. 2, 8 Trubetskaya Str., Moscow, 119991 , \\ RussianFederation \\ ${ }^{4}$ Federal Scientific Center for Medical and Preventive Health Risk Management Technologies, 82 Monastyrskaya \\ Str., Perm, 614045, Russian Federation
}

The article contains information on hazardous chemical wastes, reasons that cause their occurrence and accumulation in the environment as well as issues related to accumulation of persistent organic pollutants (POPs) in the environmental objects. The authors outline specific features of POPs and their possible influence on the environment and a human body; they also dwell on priority activities accomplished in the RF in relation to POPs after Stockholm Convention on Persistent Organic Pollution was ratified. Provisions of international law in the sphere of providing chemical safety are being consolidated now and operating bodies of Basel, Rotterdam, and Stockholm Conventions interact with each other in order to fix concentrations for chemicals which are persistent organic pollutants and to determine their low contents in wastes. The European Union countries and Canada have submitted their proposals on concentrations of 21 various chemicals in wastes for consideration by all the concerned parties. Scientific validity of the proposed concentrations has been analyzed; the analysis results are given in the article. Given the hazards caused by chemicals wastes that contain POPs for people and the environment, the authors suppose that additional research should be performed on substantiation of POPs safe concentrations in wastes. Taking into account national security and common provisions of international laws related to solving global, national, and regional tasks, the authors note that it is necessary to update legislation on state regulation in the sphere of providing chemical safety; they also give grounds and outline conceptual approaches to creation of the Federal Law "On chemical safety". The article gives a basic idea of this law; its purpose; an object of its regulation; people or economic entities whose activities are subject to its force; a place this law, when passed, is going to have in the RF federal legislation and a system of international agreements that are ratified by the RF. It should be noted that when the Federal Law "On chemical safety" is adopted, it will allow to reduce negative effects produced by hazardous chemical wastes on population and the environment and will have both medical and social-economic outcomes.

Key words: chemical wastes, persistent organic pollutants, stability, bioaccumulation, cross-border transfer, toxicity, chemical safety, international conventions, federal laws.

(C) Pushkareva M.V., Shevyreva M.P., Goncharuk N.N., May I.V., Andrishunas A.M., 2018

Mariya V. Pushkareva - Doctor of Medical Sciences, Professor, Head of Department for expert support in chemical safety sphere (e-mail: kacchem@ sysin.ru; tel.: +7 (495) 540-61-71).

Marina P. Shevyreva - Doctor of Medical Sciences, Professor, Deputy Director (e-mail: kacchem@sysin.ru; tel.: +7 (495) 540-61-71).

Nikolai N. Goncharuk - Head of informational, analytical and expert support int he sphere o biological and chemical safety (e-mail: kacchem@ sysin.ru; tel.: +7 (495) 540-61-71).

Irina V. May - Doctor of Biological Sciences, Professor, Deputy Director responsible for scientific work (e-mail: may@fcrisk.ru; tel.: +7 (342)237-25-47).

Alena M. Andrishunas - junior researcher at Laboratory for complex sanitary-hygienic analysis and inspections (e-mail: ama@fcrisk.ru; tel.: +7 (342)237-18-04). 
Occurrence and long-term storage of hazardous chemical wastes, both industrial and consumer ones, is a burning issue all over the world and in the Russian Federation as well; chemicals from such wastes can penetrate the environment and harm human health and environmental objects. The overall volume of industrial and consumer wastes accumulated and accounted in the country amounted to approximately 40.7 billion tons by the end of $2016^{1}$. But the actual amount can be even greater due to wastes accounting being a rather complicated procedure as some wastes were generated many years ago and they have been stored ever since on non-organized ("spontaneous") dumps that are detected annually. Besides, previously accumulated wastes decay, become diluted, they are exposed to weathering and wash-out, they become covered with dust or hidden by plants that grow on dumps, and experts face serious problems when they try to objectively describe consequences of these processes. Approximately 2\% out of the overall wastes mass (about 800 million tons) are hazardous wastes. Over 2006-2016 approximately $140-98$ million tons of wastes belonging to the I-IV danger categories were annually generated in Russia.

Dumps where solid household and communal wastes are stored pollute the atmospheric air, soils, underground and surface waters with heavy metals [1-4], polycyclic aromatic hydrocarbons and other persistent organic pollutants [5-8]. Hazardous pollutants penetrate natural water objects including those which drinking water is taken from to be supplied to population $[9,10]$. Some authors note that impacts exerted by such dumps cause unacceptable population health risks [11-13]. Experts detect hazardous chemical admixtures in plants tissues [14] and in biological media of animals $[15,16]$ in zones influenced by dumps where wastes are stored. Experimental and epidemiologic research confirms that hazardous chemicals typical for household and industrial wastes dumps exert negative impacts on population health, including cellular level [16-18]. Medical and demographic losses, in their turn, cause substantial economic losses, both at a regional and a country level [19, 20].

There are the following basic reasons that cause generation and accumulation of hazardous chemical wastes:

- wide application of chemicals with high toxic, mutagenic, and carcinogenic properties in industry, agriculture, and households;

- synthesis and implementation of principally new industrial chemicals that later occur in wastes but their impacts on human health and the environment are not studied sufficiently yet;

- accumulation of persistent organic pollutants (POPs) in the environment due to past-time activities;

- absence of efficient technical solutions concerning processing and recycling of hazardous chemical industrial and communal wastes, as well as absence of efficient techniques for polluted soils recultivation;

- insufficient legislative and regulatory grounds for a system of hazardous wastes treatment in the Russian Federation [21, 22].

World practice shows that legal regulations are widely used to minimize chemical risks caused by industrial and communal wastes. Thus, the Stockholm Convention ${ }^{2}$ ratified by 152 countries was adopted in order to limit or even terminate manufacturing and application of all intentionally produced persistent organic compounds (POPs); and gradually reduce and, if possible, completely terminate introduction of unintentionally produced POPs, such as dioxins and furans, into the environment. Implementation of the best available technologies is a basic way that should be applied when treating hazardous wastes.

Activities aimed at identification of dioxins and furans sources and development of emis-

\footnotetext{
${ }^{1}$ On the situation and protection of the environment in the Russian Federation in 2016: State Report. Moscow, the RF Ministry of Natural Resources and The Environment; NIA-Priroda Publ., 2017, 760 p. (in Russian).

${ }^{2}$ Stockholm Convention on Persistent Organic Pollutants. Available at: http://chm.pops.int/Portals/0/sc10/files/a/stockholm_convention text_r.pdf (access date: 15.08.2018) (in Russian).

${ }^{3}$ Basel Convention on the control of transboundary movements of hazardous wastes and their disposal. - URL: http://www.basel.int/Portals/4/Basel\%20Convention/docs/text/BaselConventionText-r.pdf (access date: 15.08.2018) (in Russian).
} 
sion surveys were accomplished within the frameworks of cooperation with the Basel Convention $^{3}$ secretariat. Besides, within the Basel convention framework, experts control transboundary movement of hazardous wastes and try to prevent transportation of hazardous wastes for their consequent disposal in countries where there are no relevant enterprises dealing with safe processing of wastes. Annually as many as 8.5 million tons of hazardous wastes are moved across state borders. The convention covers a wide range of wastes that are considered "hazardous" depending on their origin and composition.

There are more than 20 legislative acts adopted in the European Union (EU) that regulate wastes treatment. We can mention the EU Council Directive 96/61/ec dated September 24, 1996 on integrated pollution prevention and control; the EU Council Directive 2000/76/eu on incineration of wastes dated December 4, 2000; the EU Council Directive 99/31/eu on landfill of wastes dated July 16, 1999, and others. These documents envisage there should be a decrease in wastes volumes aimed for elimination, and a step-by-step transfer to their application as recycled resources. There were certain instruments applied to achieve it, in particular, new taxation on wastes sources, development of processing strategies, updating of existing schemes for quantitative and qualitative wastes parameters.

The Russian Federation is actively developing legal grounds for regulation of wastes treatment. The country ratified the Stockholm Convention in the Federal Law issued on June 27, 2011 No. 164-FL ${ }^{4}$ with an initial list containing 12 POPs. Each new chemical included into lists fixed by the Convention is to be ratified separately as per obligations accepted by the Russian Federation. When ratifying the Stockholm Convention, The Russian Federation determined the following priority activities: a ban on manufacturing and application of certain pesticides; a ban on manufacturing and application of polychlo- rinated biphenyls (PCBs) by 2025 and complete elimination of PCB-containing equipment by 2028; minimization and, if possible, elimination of unintentionally occurring POPs; control over recycling of POP-containing wastes. Polychlorinated biphenyls are industrial products that are being applied at the moment and that are to be eliminated. It is forbidden to produce them in Russia, however at present there are at least 30 thousand tons of them kept in warehouses or in technical appliances (transformers, condensers, etc.) But at the same time, the second hazardous industrial product, hexachlorobenzene, is used in pyrotechnic compounds and is still produced in the country.

The Federal Law "On industrial and consumer wastes" ${ }^{15}$. issued on June 24, 1998 No. 89FL is constantly updated. More than 80 technical, essential, and organizational corrections have been made into it since it was issued [23].

But at the same time, some issues remain vital; it is especially true for the sphere of providing chemical safety for the population [11, $24,25]$. Several authors note that legal regulation of public relations existing in the sphere can be described as disjoint; it doesn't have a unified legal ground; it can solve only some specific tasks related to providing chemical safety in different legislation spheres [26, 27].

Given all the above mentioned, lawmakers and experts have developed a draft of a basic federal law that will be entitled "On chemical safety".

A basic idea of this law, "On chemical safety", is to systematize separate legal standards concerning chemical safety issues and contained in legal acts issued in different legislative spheres; to exclude duplications and existing contradictions between such acts as regards requirements to and necessary activities aimed at providing chemical safety; to fix a set of activities necessary to ensure implementation of state policy for providing chemical safety.

The goal of the law is to create a legal

\footnotetext{
${ }^{4}$ On ratification of the Stockholm Convention on persistent organic pollutants: Federal law issued on June 27 , 2011 No. 164-FL. President of Russia: the official web-site. Available at: http://kremlin.ru/acts/bank/ (access date: 17.08.2018) (in Russian).

${ }^{5}$ On industrial and consumer wastes: The Federal Law issued on June 24, 1998 No. 89-FL (last edited on December 31, 2017). KonsultantPlus Available at: http://www.consultant.ru/document/cons doc_LAW_19109/ (access date: 17.08.2018) (in Russian).
} 
framework for implementing activities aimed at gradual reduction of risks caused by negative impacts exerted by hazardous chemical factors on population and the environment until such risks become acceptable.

The law will cover activities performed by state authorities, local authorities, juridical persons, private entrepreneurs, and citizens who participate in chemical safety provision. It is necessary to separate spheres of responsibility between state and local authorities, and it is also quite important to clarify and to enhance rules and responsibilities of citizens, private entrepreneurs, and juridical persons in the sphere of chemical safety.

This law is primarily aimed at implementation of Clauses 41 and 42 of the RF Constitution; these Clauses state that any citizen has the right for protection of his or her health and for the favorable environment; they also state that the Russian Federation is to fulfill its international legal obligations in the sphere of chemical safety.

The draft law contains a set of activities that are necessary to implement the state policy for providing chemical safety; it includes basic measures and activities performed within the frameworks of the existing Federal Laws, such as "On the basics of citizens' health protection in the Russian Federation, " On sanitaryepidemiologic welfare of the population" , "On environmental protection", "On industrial and consumer wastes" , "On safe handling of pesticides and agrochemicals" , "On industrial safety of hazardous industrial objects" , "On technical regulation" ${ }^{6}$, as well as more than 30 other federal laws dealing with some specific matters in the chemical safety sphere.

A true innovation of the law is a definition given in it to chemical safety; it is defined as "...a situation in which population and the environment are protected from hazardous chemical factors; in which acceptable levels of chemical risks are secured" (Clause 1). And here chemical risk is determined as per its classical definition, and it is "... a probability of damage done (taking its severity into account) to human health and (or) damage done (taking its severity into account) to the environment by hazardous chemical factors".

The law contains a definition of chemical carcinogens; they are substances that "cause oncologic diseases or greater risks of their occurrence".

It is extremely important that there is an attempt to determine acceptable risk in the law (Clause 1, Item 27): "an acceptable chemical risk is a level of chemical risk detected via comparison with a risk that exists in everyday life, and probable negative outcomes of which are so negligible that this risk can be considered acceptable by the society and by the state as benefits gained from a chemical factor related to the risk are worth it". At present it is the only legislative document in the RF that gives at least some criteria for assessing human health risks.

The law also envisages additional activities aimed at reducing threats, hazards, and risks for the environment and human health; they in-

\footnotetext{
${ }^{6}$ On the basics of citizens' health protection in the Russian Federation: the Federal Law issued on November 21, 2011 No. 323-FL (last edited on December 29, 2017). KonsultantPlus. Available at: http://www.consultant.ru/document/cons_doc_LAW_121895/ (access date: 29.07.2018) (in Russian); On sanitaryepidemiologic welfare of the population: the Federal Law issued on March 30, 1999 No. 52-FL (edited on July 29, 2017). KonsultantPlus. Available at: http://www.consultant.ru/document/cons_doc_LAW_22481/ (access date: 05.02.2018) (in Russian); On environmental protection: the Federal Law issued on January 10, 2002 No.7-FL (edited on December 31, 2017). KonsultantPlus. Available at: http://www.consultant.ru/document/cons doc LAW 34823/ (access date: 05.02.2018) (in Russian); On industrial and consumer wastes: the Federal Law issued on June 24, 1998 No.89-FL (edited on December 31, 2017). KonsultantPlus. Available at: http://www.consultant.ru/document/cons doc LAW_19109/ (access date: 05.02.2018) (in Russian); On safe handling of pesticides and agrochemicals: the Federal Law issued on July 19, 1997 No. 109-FL (edited on April 17, 2017). KonsultantPlus. Available at: http://www.consultant.ru/document/cons doc LAW 15221/ (access date: 05.02.2018) (in Russian); On industrial safety of hazardous industrial objects: the Federal Law issued on July 21, 1997 No. 116-FL (edited on March 07, 2017). KonsultantPlus. Available at: http://www.consultant.ru/document/cons doc LAW 15234/ (access date: 05.02.2018) (in Russian); On technical regulation: the Federal Law issued on December 27, 2002 No.184-FL (edited on July 29, 2017). KonsultantPlus. Available at: http://www.consultant.ru/document/cons_doc_LAW_40241/ (access date: 05.02.2018) (in Russian).
} 
clude development of efficient technical solutions as regards processing and recycling of chemically hazardous industrial and consumer wastes, recultivation of polluted soils; implementation of best available environmentally friendly technologies for treatment of chemically hazardous wastes; elimination of stocks containing plant protectors and agrochemicals that are no longer fit for use and persistent organic pollutants in conformity with international agreements which the Russian Federation joined.

Clause 6 enlists powers that belong to the $\mathrm{RF}$ federal public authorities in the economic safety sphere; among them it fixes monitoring of chemical risks with assessing efficiency of performed activities that are aimed at step-by-step risks reduction until they become acceptable.

The legal act highlights the significance of prophylaxis measures that are aimed at neutralizing chemical threats, preventing and reducing chemical risks. Basic measures here are provision of safe operations at chemically hazardous industrial objects; greater chemical safety of products; handling of pesticides strictly according to the standards, including their active substances and agrochemicals.

The law also fixes the significance of activities aimed at prevention and reduction of chemical risks occurring in situations when highly toxic chemicals and hazardous persistent chemical compounds are applied.

The law also envisages some measures for preventing and reducing chemical risks caused by sources of chemical hazards. Such measures include:

- preventing emergencies and (or) sabotage at potentially hazardous chemical objects;

- eliminating idle sources of chemical hazards or their processing; development and implementation of up-to-date technologies for chemical safety provision;

- working out efficient technical solutions for processing (recycling) of chemically hazardous industrial and consumer wastes as well as recultivation of polluted territories including:

- ranking and classifying potentially hazardous chemical objects and polluted territories taking into account chemicals properties, and population mortality and morbidity that depend on the environment;
- conducting inspections at potentially hazardous chemical objects and polluted territories, including inventories of enterprises that used to produce hazardous chemicals but don't function any more as well as inventories of territories polluted due to economic activities previously performed on them;

- preparing medical and sanitary profiles for territories where potentially hazardous chemical objects are located and working out measures for their elimination (processing) and (or) chemical risks reduction;

- creating regional databases on how properly and reliably potentially hazardous chemical objects are operated and regional maps showing where chemically hazardous wastes are stored in the RF regions etc.

Another substantial component of the law that helps to protect population from chemical hazards is related to measures fixed in it (Clause 15) and aimed at preventing occurrence and prevalence of health disorders caused by hazardous chemical factors; such measures include technologies applied for diagnostics, correction and prevention of health disorders associated with chemicals factors, control over threats and hazards, and a system for wider spread of information on health risks among population.

Chemical risks are gradually reduced to acceptable levels due to enhancement and development of the national system for chemical safety in the Russian Federation. This national system for chemical safety includes the following basic elements: state authorities, local authorities, juridical persons, private entrepreneurs, and citizens taking part in providing chemical safety in accordance with the RF legislation.

The national system for chemical safety has the following functions:

- monitoring of chemical risks;

- updating of legal regulation and public administration taking into account newly detected chemical risks;

- providing resources for functional elements of the national system for chemical safety;

- developing and implementing activities aimed at neutralization of chemical hazards, chemical risks prevention and reduction, providing greater security of population and territories from hazardous chemical factors as well as assessing how 
efficient all the implemented measures are.

When the Federal Law "On chemical safety" is issued, it will allow to reduce negative impacts exerted by hazardous chemical factors on population and the environment and will have both medical and socioeconomic outcomes. In particular, the law will provide additional conditions for health preservation, reduction in population mortality and morbidity, preservation of the country gene fund and keeping it at a level necessary for proper development of the society; it will help to ease social tension caused by occurrence or probability of damaging chemical factors that exert negative impacts on the country population; it will allow to decrease losses due to breaks in economic activities performed by workable population in the RF, burdens on the public healthcare system in the country, and economic damage caused by emergencies and disasters at hazardous chemical objects.

The law will become even more significant for the legal system in the RF after some provisions for implementation of international legal obligations accepted by the Russian Federation in the chemical safety sphere are included into it. It will determine political outcomes that will become obvious through greater international prestige enjoyed by the Russian Federation as well as through greater development of regional and international relations in the chemical safety sphere.

But at the same time, when the law is issued, it will require development of domestic sub-legislative scientific and methodical base as regards:

- working out up-to-date techniques for indication of the most significant hazardous chemicals in environmental objects and human biological media;

- working out up-to-date selective and sensitive identification techniques for new chemicals and mixtures for their consequent classification and marking;

- hygienic regulation for new chemicals and mixtures;

- substantiation of limitation imposed on distribution of chemicals causing the highest risks for population health and environmental objects;

- creation of state standard samples and a databank of hazardous persistent chemicals including persistent organic pollutants;
- development and implementation of up-to-date techniques, means and technologies for protection of population and the environment from hazardous chemical factors;

- development and application of means and technologies for diagnostics, treatment and prevention of health disorders caused by hazardous chemical factors;

- substantiation and implementation of medical and prevention activities for people exposed to chemical risks at potentially hazardous chemical objects as well as in zones influenced by such objects;

- creation of an efficient system for risk communications in order to improve overall culture of the RF population in the sphere related to providing chemical safety.

It will also be necessary to train and develop staff required for providing chemical safety and to improve a system of training for experts in the field including creating better conditions for:

- eliminating shortage of experts in the sphere of toxicology and occupational medicine via optimization of their training as well as making these occupations more attractive and prestigious;

- improving skills of staff, including servicing personnel, necessary for providing chemical safety when potentially hazardous chemicals objects are being operated, as well as for solving issues related to anti-terrorist and anti-sabotage protection of such objects;

- development of educational centers created in federal state scientific and educational establishments in the RF regions;

- development and implementation of educational programs and programs for subject updating on issues related to chemical risks analysis and application of chemical risks management technologies;

- performing drills on organization of interdepartmental interaction including elimination of emergency situations consequences at potentially hazardous chemical objects.

Funding. Our research was not granted any sponsors' support.

A conflict of interests. The authors state there is no conflict of interests. 


\section{References}

1. Popova E.I. Soderzhanie tyazhelykh metallov v pochve i rastitel'nosti na territorii khraneniya tverdykh bytovykh otkhodov [Heavy metals in soil and vegetation storage area solid waste]. Sovremennye problemy nauki i obrazovaniya, 2015, no. 5, pp. 652 (in Russian).

2. Yanturin S.I., Khisametdinova A.Yu., Khisametdinov F.Z. Soderzhanie rtuti v gruntovykh vodakh v okrestnostyakh sela Semenovskoe Baimakskogo raiona respubliki Bashkortostan [The content of mercury in groundwater in the vicinity of the village of Semenovskoye in the Baimaksky district of the Republic of Bashkortostan]. Ilishevskie chteniya: Sbornik materialov I Vserossiiskoi nauchnoprakticheskoi konferentsii. In: R.R. Baizigitova, ed. Sibai, 2017, pp. 161 (in Russian).

3. Shilova Yu.O., Vitkovskaya S.E. Otsenka vozdeistviya poligona tverdykh bytovykh otkhodov na soderzhanie tyazhelykh metallov v pochve i rasteniyakh [Assessment of the impact of the solid domestic waste landfill on the content of heavy metals in soil and plants]. Tendentsii razvitiya agrofiziki: ot aktual'nykh problem zemledeliya $i$ rastenievodstva $k$ tekhnologiyam budushchego: materialy mezhdunarodnoi nauchnoi konferentsii, posvyashchennoi 85-letiyu Agrofizicheskogo NII. St. Petersburg, 2017, pp. 536-539 (in Russian).

4. Hussain R., Lu K., Chao Z., Xiaofeng Z. Trace elements concentration and distributions in coal and coal mining wastes and their environmental and health impacts in Shaanxi. Environmental Science and Pollution Research China, 2018, vol. 25, no. 20, pp. 19566-19584.

5. Rocco C., Seshadri B., Adamo P., Bolan N.S., Mbene K., Naidu R. Impact of waste-derived organic and inorganic amendments on the mobility and bioavailability of arsenic and cadmium in alkaline and acid soils. Environmental Science and Pollution Research, 2018, vol. 25, no. 26, pp. 25896-25905.

6. Dagvadorzh M., Chonokhuu S., Davaasuren D., Dorzhsuren B., Borkhuu S. Soderzhanie tyazhelykh metallov v pochvakh poligona po zakhoroneniyu otkhodov v Ulan-Batore [The content of heavy metals in the soil of the landfill for waste disposal in Ulan-Bator]. Molodoi uchenyi, 2016, no. 4, pp. 169-181 (in Russian).

7. Grebeneva O.V., Sakiev K.Z., Otarbaeva M.B., Zhanbasinova N.M. Problemy zagryazneniya pochvy tverdymi otkhodami promyshlennykh predpriyatii $\mathrm{v}$ Kazakhstane [Problems of soils pollution with solid industrial waste in Kazakhstan]. Meditsina truda i promyshlennaya ekologiya, 2014, no. 8, pp. 9-13 (in Russian).

8. Nie E., Zheng G., Shao Z., Yang J., Chen T. Emission characteristics and health risk assessment of volatile organic compounds produced during municipal solid waste composting. Waste Management, 2018, no. 79, pp. 188-195.

9. Petrovic M., Sremacki M., Radonic J., Obrovski B., Miloradov M. Health risk assessment of PAHs, PCBs and OCPs in atmospheric air of municipal solid waste landfill in Novi Sad. Serbia. Science of The Total Environment, 2018, vol. 644, pp. 1201-1206. DOI: 10.1016/j.scitotenv.2018.07.008

10. Turetskaya I.V., Potaturkina-Nesterova N.I., Shrol'O.Yu., Panteleev S.V., Nemova I.S. Otsenka zagryazneniya tyazhelymi metallami poverkhnostnykh vod ozera $\mathrm{v}$ raione poligona [The estimation of open lake water pollution with heavy metals in the area of industrial waste burial]. Fundamental'nye issledovaniya, 2012, no. 3-3, pp. 539-541 (in Russian).

11. Kleyn S.V., Vekovshinina S.A., Balashov S.Yu., Khoroshavin V.A., Ukhabov V.M. Gigienicheskaya otsenka kantserogennogo riska zdorov'yu naseleniya, prozhivayushchego v zone vliyaniya mest skladirovaniya otkhodov gorno-obogatitel'nogo kombinata [Hygienic evaluation of the carcinogenic risk to health of the population living in the zone of the exposure to places of the burial storage of waste of mining and processing enterprises]. Gigiena i sanitariya, 2018, vol. 97, no. 1, pp. 10-15 (in Russian).

12. Hsieh Y.-K., Chen W.-S., Zhu J., Wu Y.-J., Huang Q. Health risk assessment and correlation analysis on PCDD/FS in the fly ash from a municipal solid waste incineration plant. Aerosol and Air Quality Research, 2018, vol. 18, no. 3, pp. 734-748.

13. Yushin V.V. faktory riska zdorov'yu naseleniya ot vozdeistviya vybrosov poligona TKO g. Kurska [Risk factors to the health of the population from the impact of the emissions from the Kursk landfill site]. Pokolenie budushchego: vzglyad molodykh uchenykh: sbornik nauchnykh statei 4-i mezhdunarodnoi molodezhnoi nauchnoi konferentsii: $v 3$ tomakh, Moscow, 2016, pp. 154-157 (in Russian).

14. Barquero J.I., Rojas S., Esbrí J.M., García-Noguero E.M., Higueras P. Factors influencing mercury uptake by leaves of stone pine (Pinus pinea L.) in Almadén (Central Spain). Environmental Science and Pollution Research, 2017, pp. 1-9. DOI: 10.1007/s11356-017-0446-8 
15. Rumak V.S., Umnova N.V., Levenkova E.S., Turbabina K.A., Pivovarov E.A., Shelepchikov A.A., Pavlov S.D. Dioksiny v srede i organizme zhivotnykh vblizi poligona otkhodov proizvodstva i potrebleniya: $\mathrm{k}$ metodologii otsenki riska dlya zdorov'ya naseleniya [Dioxins in the environment and the body of animals near landfill: to the methodology of public health risk evaluation]. Ekologiya cheloveka, 2017, no. 10, pp. 9-15 (in Russian).

16. Luzhetsky K.P., Kleyn S.V., Vekovshinina S.A., Tsinker M.Yu. Faktory riska narushenii lipidnogo obmena u naseleniya, prozhivayushchego $\mathrm{v}$ usloviyakh mnogosredovoi ekspozitsii kadmiem $\mathrm{i}$ mysh'yakom [Risk factors of lipid metabolism disorders in residents of multi-environmental exposure to cadmium and arsenic]. Meditsina truda i promyshlennaya ekologiya, 2016, no. 12, pp. 25-29 (in Russian).

17. Zemlyanova M.A., Tarantin A.V. Narusheniya belkovogo profilya cheloveka v usloviyakh vozdeistviya tyazhelykh metallov [Violations of human protein profile in heavy metals exposure]. Ekologiya cheloveka, 2012, no. 7, pp. 7-14 (in Russian).

18. Amirova Z.K., Speranskaya O.A. Novye stoikie organicheskie supertoksikanty i ikh vliyanie na zdorov'e cheloveka [New persistent organic supertoxicants and their effect on human health]. Moscow, 2016, 169 p. (in Russian).

19. Popova A.Yu., Zaitseva N.V., May I.V., Kir'yanov D.A. Metodicheskie podkhody k raschetu fakticheskikh i predotvrashchennykh mediko-demograficheskikh i ekonomicheskikh poter', assotsiirovannykh s negativnym vozdeistviem faktorov sredy obitaniya [Methodological approaches to the calculation of actual and prevented as a result of the control and supervisory activities, medical-demographic and economic 95 losses, associated with the negative impact of environmental factors]. Gigiena $i$ sanitariya, 2015, vol. 94, no. 7, pp. 95-99 (in Russian).

20. Ryzhakov S.A., Zaitseva N.V., May I.V., Alekseev V.B., Podluzhnaya M.Ya., Kir'yanov D.A. Makroekonomicheskii analiz poter' zdorov'ya, veroyatnostno obuslovlennykh emissiyami zagryaznyayushchikh veshchestv v atmosfernyi vozdukh [Macroeconomic analysis of health losses probabilistically caused by emissions of pollutants into the atmosphere]. Permskii meditsinskii zhurnal, 2009, vol. 26, no. 3, pp. 139-143 (in Russian).

21. Yastrebov A.E. Pravovye aspekty ekonomicheskogo regulirovaniya $\mathrm{v}$ oblasti obrashcheniya $\mathrm{s}$ otkhodami proizvodstva i potrebleniya [Legal aspects of economic regulations of production and consumption waste management]. Severo-Kavkazskii yuridicheskii vestnik, 2016, no. 2, pp. 85-91 (in Russian).

22. Kozhevnikov O.A. Sovershenstvovanie sudebnoi praktiki po voprosam obrashcheniya s otkhodami proizvodstva i potrebleniya kak odna iz zadach "obnovlennogo" Verkhovnogo Suda RF [Improvement of judicial practice on the management of production and consumption wastes as one of the tasks of the "renewed" Supreme Court of the Russian Federation]. Administrativnoe i munitsipal'noe pravo, 2014, vol. 81, no. 9, pp. 975-980 (in Russian).

23. Ostrovskii N.V. Evolyutsiya federal'nogo zakona "Ob otkhodakh proizvodstva i potrebleniya" [Evolution of the federal law "on production and consumption waste"]. Voprosy upravleniya, 2015, vol. 32, no. 1, pp. 170-176 (in Russian).

24. Stepanova I.P., Krasil'nikova S.D. Otsenka kantserogennogo riska dlya zdorov'ya naseleniya $\mathrm{v}$ rezul'tate vozdeistviya khimicheskikh veshchestv pri khranenii tverdykh gal'vanicheskikh otkhodov [Assessment of the carcinogenic risk for public health as a result of exposure to chemicals in the storage of solid galvanic waste]. Uchenye zapiski Komsomol'skogo-na-Amure gosudarstvennogo tekhnicheskogo universiteta, 2013, vol. 1, no. 2 (14), pp. 111-116 (in Russian).

25. Rastanina N.K., Krupskaya L.T., Golubev D.A., Cherentsova A.A. Otsenka riska dlya zdorov'ya naseleniya, svyazannogo s tekhnogennym zagryazneniem ot otkhodov byvshego gornogo predpriyatiya "Khrustal'nenskii GOK" [Evaluation of health risk due to pollution with waste of the abandoned khrustalnensky mining and processing plant]. Gornyi informatsionno-analiticheskii byulleten' (nauchnotekhnicheskii zhurnal), 2017, no. 12, pp. 88-95 (in Russian).

26. Vekovshinina S.A., Kleyn S.V., Khankhareev S.S., Makarova L.V., Madeeva E.V., Boloshinova A.A. Otsenka kachestva sredy obitaniya i riskov dlya zdorov'ya naseleniya g. Zakamenska - territorii dlitel'nogo khraneniya otkhodov dzhidinskogo vol'framo-molibdenovogo kombinata [The assessment of 
environmental quality and risks for thepopulation of the city of Zakamensk - territory of long-term storage of waste of dzhidinsky tungsten-molybdenum combine]. Gigiena i sanitariya, 2017, vol. 96, no. 1, pp. 15-20 (in Russian).

27. Rakhmanin Yu.A., Sinitsina O.O. Sostoyanie i aktualizatsiya zadach po sovershenstvovaniyu nauchno-metodologicheskikh i normativno-pravovykh osnov $\mathrm{v}$ oblasti ekologii cheloveka $\mathrm{i}$ gigieny okruzhayushchei sredy [Status and actualization of tasks to improve the scientific-methodological and regulatory frameworks in the field of human ecology and environmental hygiene]. Gigiena $i$ sanitariya, 2013, no. 5, pp. 4-10 (in Russian).

Pushkareva M.V., Shevyreva M.P., Goncharuk N.N., May I.V., Andrishunas A.M. The RF Federal law "On chemical safety" as a tool for minimizing population health risks caused by dealing with hazardous chemical wastes. Health Risk Analysis, 2018, no. 3, pp. 31-39. DOI: 10.21668/health.risk/2018.3.04.eng

Received: 19.08.2018

Accepted: 20.09 .2018

Published: 30.09 .2018 